\title{
Kaija Saariaho and Her Laterna Magica
}

\section{T. V. Tsaregradskaya}

The Gnesin Russian Academy of Music, 30-36, Povarskaya ul., Moscow, 121069, Russian Federation

For citation: Tsaregradskaya, Tatiana. "Kaija Saariaho and Her 'Laterna Magica"' Vestnik of Saint Petersburg University. Arts 11, no. 4 (2021): 607-635. https://doi.org/10.21638/spbu15.2021.403

Nowadays Kaija Saariaho is one of the most successful composers in the field of contemporary classical music. A former student of Tristan Murail, she works in the direction initiated by socalled spectral composition, composing extremely colourful and poetic pieces that are highly appreciated by music critics. One of her orchestra compositions, Laterna Magica, based on the memoirs by Ingmar Bergman and commissioned by the Berliner Philharmoniker Orchestra, premiered in 2009 and became a hit - it was performed more than thirty times after the premiere. This successful piece is the main object of the analysis which is performed according to ideas of Saariaho expressed in her theoretical articles. One of the most interesting ideas about music form proposed by the composer is the idea of "polyphony of processes", which means that different parameters of composition are realized in different schemes that do not intersect but act as separate phenomena creating an impression of both independence of the parameters and their interaction at the same time. Such parameters as rhythm, melodic ideas, application of text, tempos, textures and their combinations as well as orchestration and harmony have their own profile and are constructed according to different schemes. Besides music itself, a text by Saariaho written for the premiere of the piece is analysed and interpreted as a special case of a "composer's vision" which shows specific angles in the author's perception.

Keywords: Kaija Saariaho, contemporary classical music, Laterna Magica, Ingmar Bergman, polyphony of parameters, independent compositional parametrical schemes, composer's vision.

Spectral music originated at the end of the 1970s and developed during more than forty years. Its leaders - Gérard Grisey and Tristan Murail as well as their disciples were eager to develop their compositional activity as an alternative to serial and post-serial music. The protest against "sterile", "unhuman" sound of the Darmstadt school led to radical changes in the whole spectrum of musical ideas and a search for the true nature of musical material. Musical spectralism became the leading trend in music composition development and its ideas are still popular among the younger generation of composers.

Today, after years of spectral developments, the degree of protest has changed to a more balanced position. New trends appeared in the works of composers who were designated by French musicologist Damian Pousset as "post-spectralists" [1, p. 69]. They are Marc-André Dalbavie, Kaija Saariaho, Philippe Hurel, and Bruno Mantovani. Their aim can be described as a way to more conventional means of composing. Their ideas even put in question the identity of the aforementioned young composers as spectralists (for example, renowned Flemish theorist Célestin Deliège had doubts on this point [2, p.69]). The fact is that in such compositions as Symphonietta (2005), Sonnets (2007), and Concerto for Flute (2007) by Dalbavie, and in such pieces by Saariaho as Orion (2002) and Laterna

(C) St. Petersburg State University, 2021 
Magica (2008), the composers use much more of a traditional idiom than in their earlier works. Their contemporary Philippe Manoury ironically referred to this as the "Philharmonic style" [3].

"Philharmonic style" means that composers, feeling obligated to cooperate with large orchestras, tend to hear their music on great venues and suggest it to the general public. Kaija Saariaho was moving in the direction of "beautiful music" from the beginning of her career, and this possibly attracted the attention of critics and musicologists: we can state that she became one of the most popular figures in contemporary classical music. Publications on Saariaho were published in Finnish (monograph by P.Moissala [4]), and then appeared in English [5] and Russian [6; 7] as well as in other languages. Avant-garde rhetoric needed to be simplified, the means of expression had to be made a little bit more conservative and communicative. The authors moved to a dialog with the public, to the simplification of the idiom. Saariaho made the same turn: she developed an outstanding compositional mastery, the ability to write really beautiful music without making it too complicated inside the realm of academic art. In her own words, "the art music of our time is not elite music but an alternative movement $\langle\ldots\rangle$ the task of today's artist is to nurture with spiritually rich art" [4, p. 24]. Among her compositions from the last two decades, one became a "hit" of symphonic concerts programmes: it is a piece named Laterna Magica for a large orchestra (2008). The composition was commissioned by the "doyen" of European orchestras - the Berliner Philarmoniker, one of the most outstanding world performers.

It is well known that Laterna Magica, or "The Magic Lantern" was created in the $17^{\text {th }}$ century as a machine for showing moving pictures. It is believed that this machine started the entire story of contemporary cinematograph. Laterna Magica is also the title of Ingmar Bergman's book, the memoire of the Swedish filmmaker [8].

This particular book served as the starting point for Kaija Saariaho's piece.

\section{Saariaho and literature}

Laterna Magica by Bergman was not the first book which inspired Saariaho in her composition activity. Her first piece for orchestra with live-electronics has the title Verblendungen (1984) and was inspired by the novel Die Blendung by German-language author Elias Canetti. As a main idea, the composer develops the concept of "blinding" which vanishes gradually; the man who is blinded begins to differentiate the light from the dark, see the contours, and define shape: "When I began to work on Verblendungen, I've read the book by Elias Canetti and I had an idea of optic dazzlement. The idea has proliferated, and I began to think about the cause of a man who is blinded and then sees the light" [9]. As Pirkko Moisala, Saariaho's biographer, notes: "Canetti examines how people can be dazzled by an abstract notion that renders them incapable of perceiving other things. This became the core metaphor for Saariaho's composition" [4, p. 31].

The solo piece Laconisme d'Aile (1982) for flute was based on poems by Saint-John Perse, and in Sah den Vögeln for soprano and instrumental ensemble the texts by American underground poets served as a source of inspiration. The Violin Concerto Graal Théâtre started with the novels by Florence Delay and Jacques Roubaud published in "Graal Théâtre" (Gallimard, 2005) where the legends about King Arthur and the Knights of the Round Table were mixed with the Graal legends. Literary impulses also can be discovered in the orchestra piece Du Cristal...à la fume (1989) based on the book by French philosopher 
Henri Atlan Entre le cristal et la fumee; the composition Circle Map (2012) was inspired by Persian poet Jalāl ad-Dīn Muhammad Rūmīi, and many other literary sources served as the starting point for Saariaho's compositions.

Saariaho provides a detailed feature of her literary interests in "My library from the words to the music" (1987): “The books are present in my music everywhere" [10, p. 14].

\section{The beginnings of Laterna Magica}

Saariaho writes: "Laterna Magica (The Magic Lantern) alludes to the autobiography of the same name by film director Ingmar Bergman. The book caught my eye after many years whilst I was tidying my bookcases in autumn 2007.

In time, as I read the book, the variation of musical motifs at different tempos emerged as one of the basic ideas behind the orchestral piece on which I was beginning to work. Symbolising this was the Laterna Magica, the first machine to create the illusion of a moving image: as the handle turns faster and faster, the individual images disappear and instead the eye sees continuous movement.

Musically speaking, different tempos underline different parameters: the rhythmic continuity is accentuated at relatively fast tempos, whereas delicate shades require more time and space for the ear to interpret and appreciate them.

While I was working with tempos, rhythms with different characters became a major part of the piece's identity: a fiery dance-rhythm inspired by flamenco, a shifting, asymmetrical rhythm provided by speech and an accelerating ostinato that ultimately loses its rhythmic character and becomes a texture.

In contrast to this, there emerged music without a clear rhythm or pulse. This material is dominated by strongly-sensed colourful planes and airy textures, such as the unified colour of six horns, which divides the orchestral phrases. This use of horns points to Bergman's film Cries and Whispers, in which the scenes are often changing through sequences of plain red colour.

When reading the autobiography, I was also touched by the way Bergman described the different lights which his favorite photographer, Sven Nykvist, was able to capture with his camera. Part of the text found its way into the piece in German - for the work was commissioned by the Berlin Philharmonic. The extract, in English, goes as follows:

Gentle, dangerous, dream-like, lively, dead, clear, hazy, hot, strong, naked, sudden, dark, spring-like, penetrating, pressing, direct, oblique, sensuous, overpowering, restricting, poisonous, pacifying, bright light. Light.

Paris, 22 March 2010

Kaija Saariaho" [11].

Laterna Magica was first performed by the Berliner Philharmoniker in Berlin under the baton of Simon Rattle on the $28^{\text {th }}$ of August 2009 and a few days later in Lucerne. After the premiere, it was played more than 20 times in different halls and cities, including BBC Proms under the baton of Juanjo Mena. The piece was highly praised by experts, critics and the press. Joshua Kosman of the San Francisco Chronicle wrote: "'Ingratiating' is a surprising way to describe a work by a composer whose language is often abstract, even austere. Yet Laterna Magica, which draws both its title and some narrative inspiration from the autobiography of the Swedish director Ingmar Bergman, is packed with arresting and oddball 
inventions [12]. Joe Cadagin of the San Francisco Classical Voice remarked, "In an almost cinematographic manner, Saariaho depicts shifting lighting effects by juxtaposing blocks of sound dominated by various tone colours and acoustic effects similar to Berlioz's use of harmonics. At certain points, the horns emerge in a kind of drooping chorale meant to symbolize the colour red. Wind chimes and celeste sparkled on the surface of a shimmering string halo, which required the string section to play almost at the point of inaudibility" [13]. The piece was also praised in the Promenade-concerts program: "the sound world, which is created by Saariaho in 'Laterna Magica', is almost impossible to describe. $<\ldots>$ In some ways it reminds the piece of Unsuk Chin Rocana (where the play of light is also embodied), but the effect in Saariaho's piece is much more subtle and effective. It is evident that each moment is so fleeting — the breathing of the winds, marimba's ghostly radiance and everything is moving through the flow of changing melodic contours $\langle\ldots\rangle$ After about 20 minutes, the piece dissipates into a few wispy tendrils of orchestral sound" [14].

Such reviews confirm that Saariaho produced an intriguing and artistically outstanding work. The question therefore arises, how was this masterpiece made? What are the compositional principles of the piece? Investigating the Laterna Magica's poetic is the aim of this article.

At first glance, the piece seems to develop very smoothly, and this makes the analysis difficult. Fortunately, Saariaho has explained some features of her compositional method in the article "Timbre and harmony" (1987): "From my earliest compositions I was especially interested in the development of musical form: in practice this became the basis of my creative work. When I say 'form' I mean precisely the idea that Wassily Kandinsky defined as the following: 'Form is the external manifestation of inner meaning' (Kandinsky: The Spiritual in Art, 1969). Hence I have never referred to pre-established formal structures in my work. It is through an overall idea of form that I approach different musical parameters and their special problems" [15, p.93]. In the same article, the composer explained the way she dealt with different parameters.

Saariaho showed the possibilities of multidimensional crossings of parameters in the piece Verblendungen for orchestra and electronics (1984) (ex. 1).

Here, it is possible to see the composer's graphical schemes of different parameters. How did they arise?

The translation of the title Verblendungen - "Blinding" - displays different shades of meaning. Optical "blinding" means a short-time loss of vision as a result of an optical attack - for example an unexpected encounter with a bright source of light. When an individual is temporarily blinded, their vision gradually returns and the contours of everything around them gradually become clearer. As a result, the graph presentation of orchestral density and dynamics begins with the greatest intensity (it is possible to refer to it "from the highest point of the spring"), and then vanishes. The explanation of opposite motion in the presentation of texture can be the same: homophonic texture displays its maximum at the beginning and minimum in the end while polyphonic texture displays the opposite motion.

Saariaho explains that the idea of different graphical representations for different parameters appeared as a result of her work with computers and was founded on the notion of "transition" and a multidimensional system. The search for the means of dealing with different parameters grew into a phenomenon which was called "polyphony of processes" by M.A. Dalbavie [16, p. 51]. 

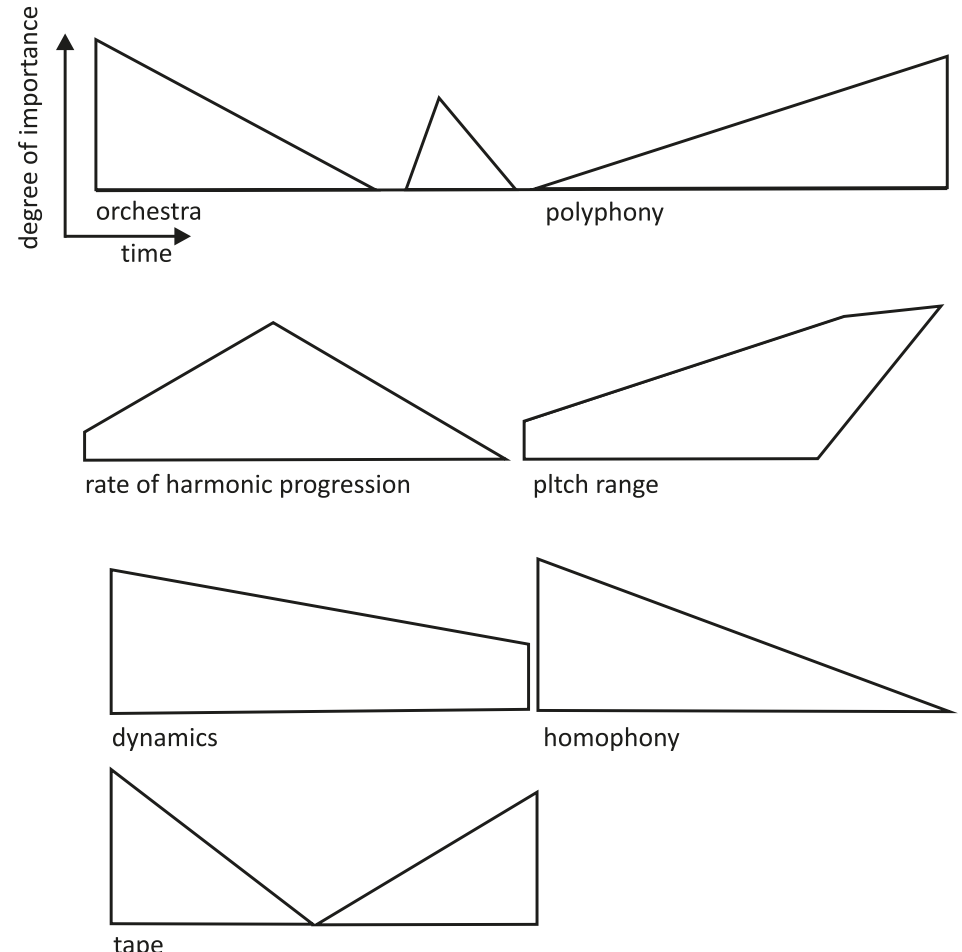

Example 1. "Curves for the evolution of the compositional parameters of Verblendungen. For each curve, time is represented on the vertical axis" $[15, \mathrm{p} .107]$

The area of transition can be compared to the "liminality" notion developed by G. Grisey. Liminality, a term borrowed from psychology, refers to thresholds, boundaries which are transgressed or never seem to have existed in the first place. It explores compositional aesthetics which have foregrounded this liminality, especially the liminality which has arisen between harmony and timbre. In the process, it proposes several interpretations of liminality, from radical expansion to disorienting ambiguity and to vivid tension between its constituents. As J. Harmeyer specifies, "Liminality has become one of the primary aesthetic concerns for a group of French composers, commonly known as the spectralists, who came into artistic maturity in Paris in the 1970s <...> Olivier Messiaen, an important mentor to most of these composers, can be seen as a forerunner, while the Finnish composer, Kaija Saariaho, who settled in Paris in the 1980s, familiarized herself with their aesthetic positions" [17, p.4]. Saariaho explained the initial idea of Verblendungen as an "impossible" form, composition which begins with the highest point and develops through the deployment of activity after the first splash of energy.

This "impossibility" of the general form deployment activated the dynamic development of different parameters. For each parameter, a specific curve of evolution was developed which had to be coordinated with each other. The interaction of parameters creates points of climax which form the general contour. Imposing the curves on each other gave the possibility of realizing this composition literally in seconds. We are going to try to analyse Laterna Magica with the help of the "polyphony of processes" notion. It should be 
emphasized that this analysis is not based on any of Saariaho's sketches: we will apply her own ideas expressed in the 80 s to the piece which was composed much later.

\section{Preliminary notes on structure}

Laterna Magica is a single continuous movement, but this continuity is not so consistent. Certainly, the interpretation of the composition as two-movement (attacca) is also possible. As long as Bergman's text plays a sufficient part in the composition, we can divide the two movements on the basis of text distribution: the first movement (bars 1-224) can be separated on the basis of verbal text, murmured by orchestra musicians, and the second movement (bars 226-542) is fully instrumental (no text added). As an additional argument in this interpretation, bar 225 can be considered as the pivotal - there we find General Pause (G. P.) with fermata, the only one in the whole piece, clearly dividing the piece into two large sections. The whole length of the piece is 542 bars - so the relationship between the two sections $(224+318$ bars $)$ can be interpreted formally, regardless of metric and rhythmic fluctuations as an imprecise proportion 2:3.

As a basis of construction for the first section, the composer used a text fragment from Bergman translated into German. On her website, Saariaho quotes it in English: "Gentle, dangerous, dream-like, lively, dead, clear, hazy, hot, strong, naked, sudden, dark, spring-like, penetrating, pressing, direct, oblique, sensuous, overpowering, restricting, poisonous, pacifying, bright light. Light" [11].

\section{Setting the text}

Saariaho cuts this rather long chain of light descriptions into short fragments which she enlarged with repetitions and thickened through orchestral texture. The words are performed by orchestra musicians and the density of this "whispering choir" gradually increases: from two performers in bars 13-14 to almost the entire orchestra in bar 223 (ex. 2).

The next appearance of the Sprechchor occurs in bars 20-21:

"milde, milde, milde, milde, milde, milde Licht" (1, 2, 3 flutes).

Bars 80-84:

"Das milde gefärliche Licht

Das traumhafte Licht

lebendige Licht. Licht" (all the woodwinds).

Bars 139-162:

"Das milde Licht [all the woodwinds and brass]

gefärliche Licht

das traumhafte Licht traumhafte Licht

das lebendige tote klare Licht

diesige heisse heftige kahle Licht

Licht".

Bars 166-177:

"Das plötzliche dunkle frülingshafte einfallende Licht.

Nach aussen dringende aussen dringende gerade Licht

schrage sinnliche Licht 


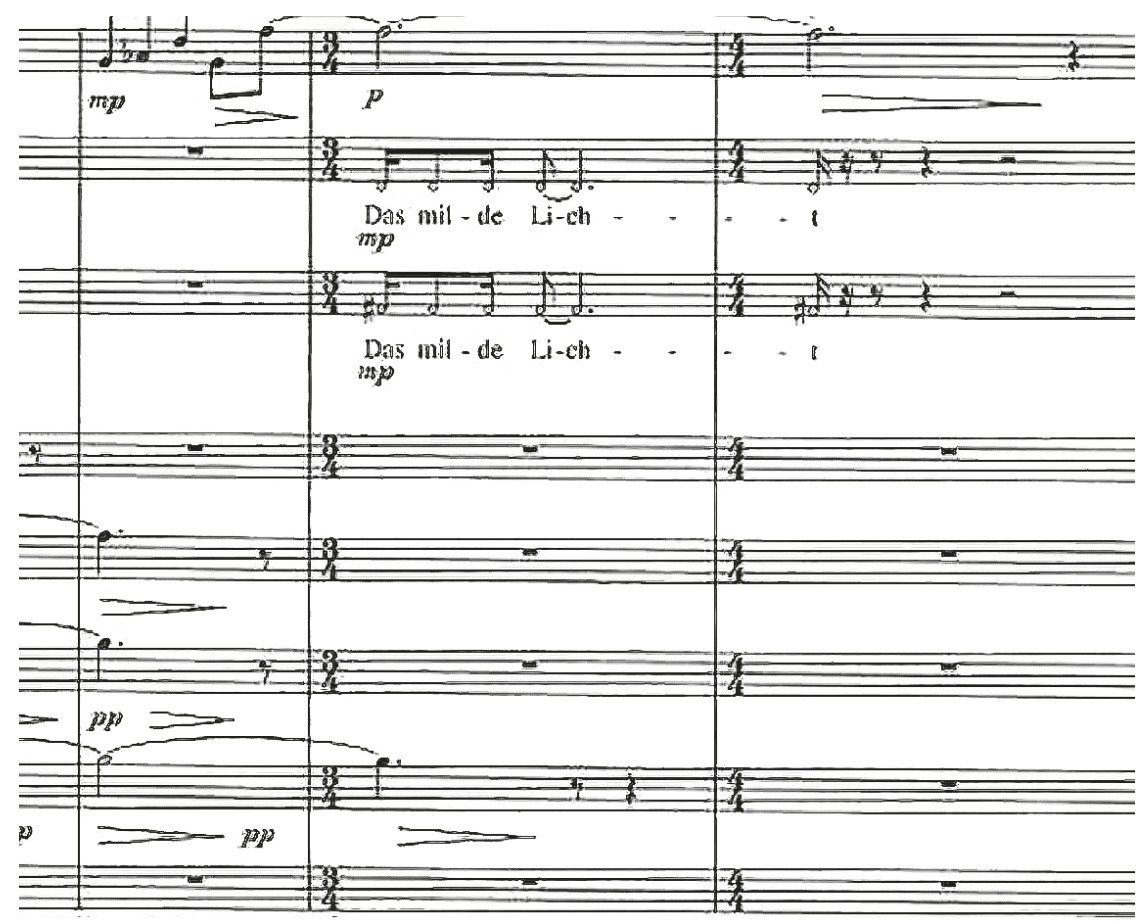

Example 2. Bars 13-14 Das milde Licht (2 ${ }^{\text {nd }}$ and $3^{\text {d }}$ flutes)

begrenzende Licht" (wind and brass instruments).

Bars 194-201: "begrenzende Licht, begrenzende Licht";

Bars 202-207: "giftige, giftige, giftige, giftige, giftige, giftige, giftige Licht";

Bars 208-213: "beruhigende Licht. Licht" (the same instrumentation).

Bar 217: "helle Licht" (the same instrumentation).

Bars 218-221: "helle, helle, helle Licht (the same instrumentation) (see: ex. 3).

The lengthening and shortening of lines remind us of a principle used in the sphere of visual poetry beginning from antiquity till the $20^{\text {th }}$ century (Mallarme, Apollinaire). The play with the length of the line forms a kind of rhopalic where each line is lengthened by a word. It is especially evident in bars $162-167$, where the number of iterations makes a progression (2, 3, 4 words). The longest line has 7 iterations, with the combination "poisonous light". After this, the number of words in a line gradually decreases. It is not so surprising to find such experiments with text in Saariaho's output: besides the fact that she is a poetry admirer, she also is a connoisseur of poetic forms. The composer herself confirms: "In my childhood poetry captivated me above all, and when I seriously began to set down on paper the music that came to me, this music often took form thanks to a poem" [10, p. 12]. Among her favourite authors are Virginia Woolf and Marcel Proust:

Virginia's Woolf's The Waves, a novel in which creative intelligence and complex metaphors combined, reflects particularly well what I was looking for in my music. The richness of Woolf's language escapes simplistic interpretation, and I sought ways of achieving a similarly prismatic language in music. This question was amplified by my reading Proust's In search of Lost Time; I was more and more interested by the exactitude of language. I still remember those sunlit days when, recovering from a throat infection, I savored Swann's love $<\ldots>$ Behind me I heard Pierre 


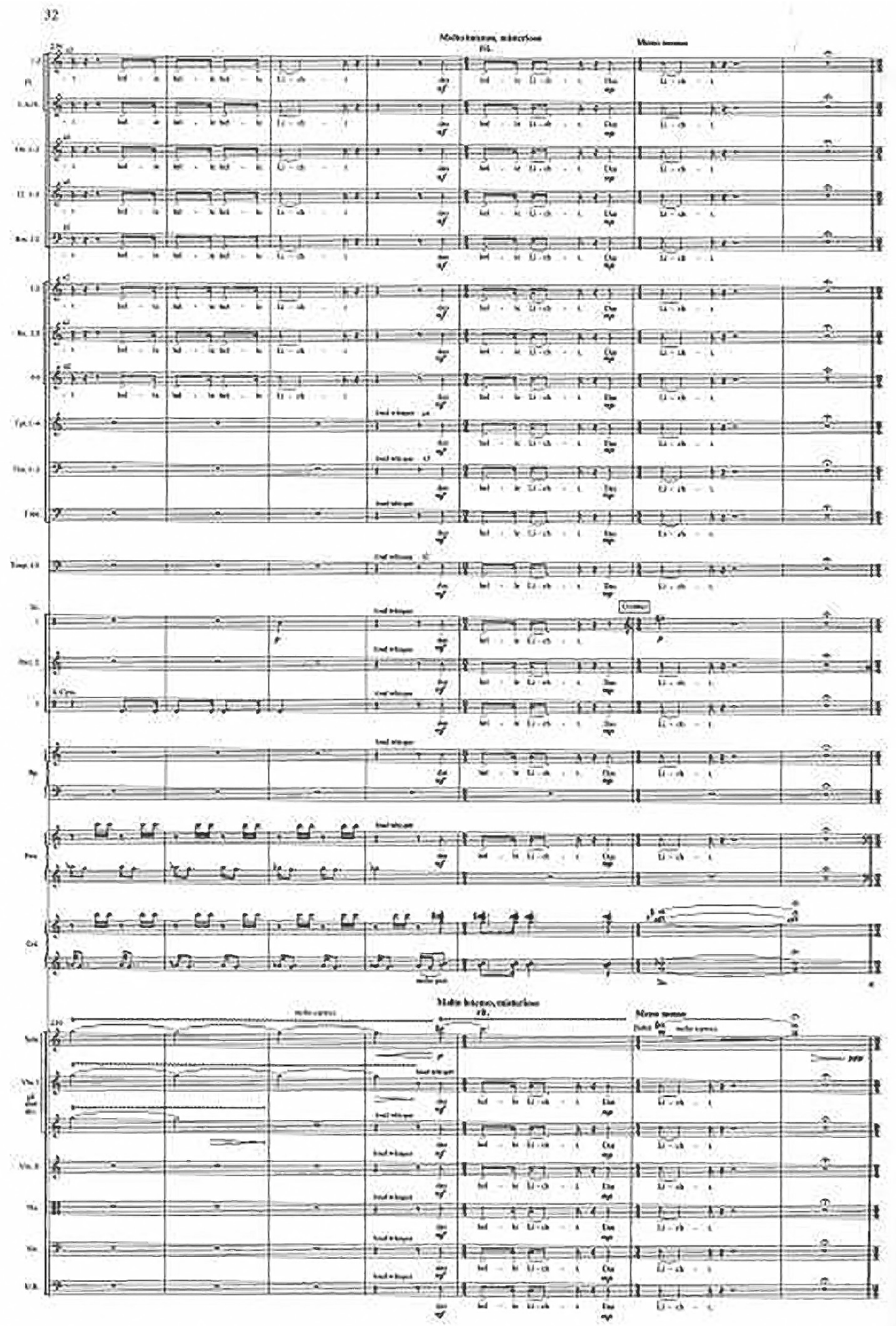

Example 3. Bars 222-224 
Boulez's Structures II which, aside from those few days, I never appreciated. The cold intelligence of this music mixed with Proust's text, and the text illuminated Boulez's French world in a new way, by giving him the heat that had otherwise been missing [10, p. 12-3].

The first section of Laterna Magica ends with an almost full Sprechchor and a full bar fermata. The lines constructed by Saariaho from Bergman's characteristics create a sort of strophic framework:

$$
\begin{aligned}
& \text { Strophe } 1 \text { - bars 1-13 } \\
& \text { Strophe } 2 \text { - bars 14-22 } \\
& \text { Strophe } 3 \text { - bars 23-101 } \\
& \text { Strophe } 4 \text { - bars 102-224 }
\end{aligned}
$$

But since these "strophes" are not at all equal (13, 9, 78, 122 bars) and are analysed only from a textual point of view, we need to consider musical material.

\section{On musical material in the 1 st section}

The first musical element of Laterna Magica is the chord played by six horns at the very beginning. It signifies the starting point of the composition (ex. 4).

Its function, according to Saariaho, is to present a colourful "spot" played by six horns dividing orchestral phrases. This six-tone chord can be reduced to the chord h-g-d-fis with a division between g-as and d-es. According to Philip Singleton [16,] we can treat it as an "all-interval chord" in terms of American set theory. And the specific feature of this chord is its closeness to some spectral models. However, Saariaho insists that she always corrects spectral models by her ear (ex. 5).

This chord functions in the strophe 1 as a beginning, and Sprechchor - as an ending. But in further development inside the "strophes", French horn chords lose their beginning function. They acquire their own logic of deployment which could be designated as "harmonic" and only partly interacts with other compositional elements. Besides the chords, we can also designate several kinds of musical material: one is reminded of Saariaho's description of strongly sensed colourful planes and airy textures and music without a clear rhythm or pulse which have mostly a melodic representation; another one is based on ostinato structures.

\section{Melodical structures}

After the first horn chord, we hear a melodic element which will appear in the course of the piece rather frequently (see: ex. 6)

Wide intervals make this motive look like "broken chord", wide leaps add expressivity. It is distinguished by its instrumentation: the contour is performed by piano, harp and vibraphone, doublings are designed in Klangfarben manner:

as-g - trombones

d-ges - trumpets and violins

ges- $f$ - oboes.

One of the specific sound qualities is a sort of "defocusing" of sound: an appearance of the last dyad "ges-f" is accompanied by an "echo-effect" (a delayed additional appearance of the abovementioned sounds in the next bar). This "echo-effect is not accidental 


\section{LATERNA MAGICA}

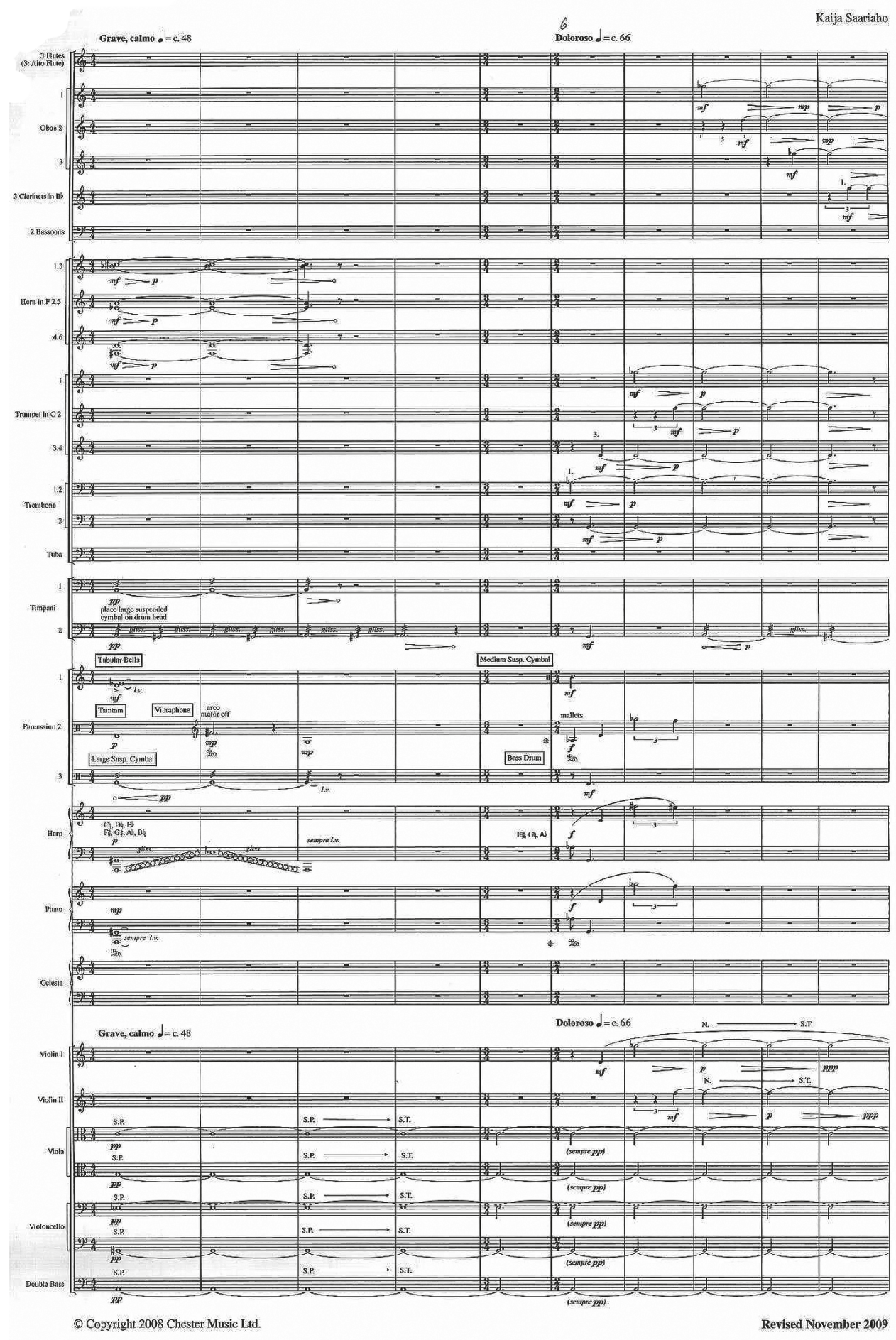

Example 4. $1^{\text {st }}$ page of the score 


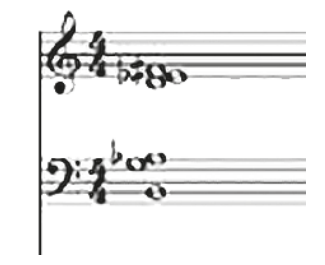

Example 5. The sixtone chord

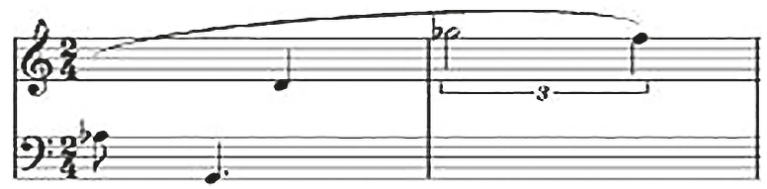

Example 6. Melodic element, bars 6-7

and very characteristic; we can identify it also in the work of other composers devoted to spectral methods. One of the most distinguished theorists of spectralism Julian Anderson in analysing similar cases in Tristan Murail's work points out some peculiarities: "Each note played by the horn is imitated by the ensemble of nine players after a varying timelag: the work is, in fact, an instrumental simulation of the analogical studio technique known as the 'reinjection loop'. A sound played live is recorded by a tape machine passed on to a second machine which plays the recorded sound, then sent back to the first machine to be combined with a new recorded sound, which is in turn played by the second tape machine and so on" [18, p. 3].

The effects of reverberation are frequent in the moments when the diagonal presentation of harmony takes place. It is one of the favourite effects in Saariaho's work and if it was performed by electronics in her earlier compositions, now she uses it in her harmonic writing for the orchestra.

The second strophe also contains a harmony, a motive and a "conclusion" of Sprechchor; its structure is similar to the first one. It also has an upward direction, but its contour is different: it goes spirally, and this modus operandi is transferred to the following melodic structures as we see in the third motive.

\section{Third motive}

The melodic nature of these constructions are similar to Webern's atonal thematicism and partly to Skryabin's short themes as well as to Ives's The Unanswered Question. All these motives are flexible and asymmetrical in Expressionistic manner: they are not iterated literally but every time appear as short, varied, very impulsive and angular (ex. 7).

The third component - whispering Sprechchor - reminds us about the traditions of Sprechchor in the works of $20^{\text {th }}$ century authors. The usage of word as a separate phonetic material for further development and variation became a common feature for many composers: A. Schoenberg, I. Stravinsky, D. Milhaud, A. Honegger, G. Enescu, C. Orff, F. Busoni, K. Weil, H. Eisler and others. The phonetics of the words for this particular music was chosen by Saariaho according to the preference of whistling and hissing components. For example, the key word - Licht - has two last sounds which accentuate rustling coloration stressed by separating the two last sounds: $c h-t$.

Laterna Magica is not the first composition where Saariaho uses the sound of speech in her instrumental music. In the flute piece Laconisme de 1'Aile (1982), the flutist first recites the verses of St. John Perse, and then the composer introduces flute elements into the declamation which gradually displace the text. In the end, the sound of the flute re- 


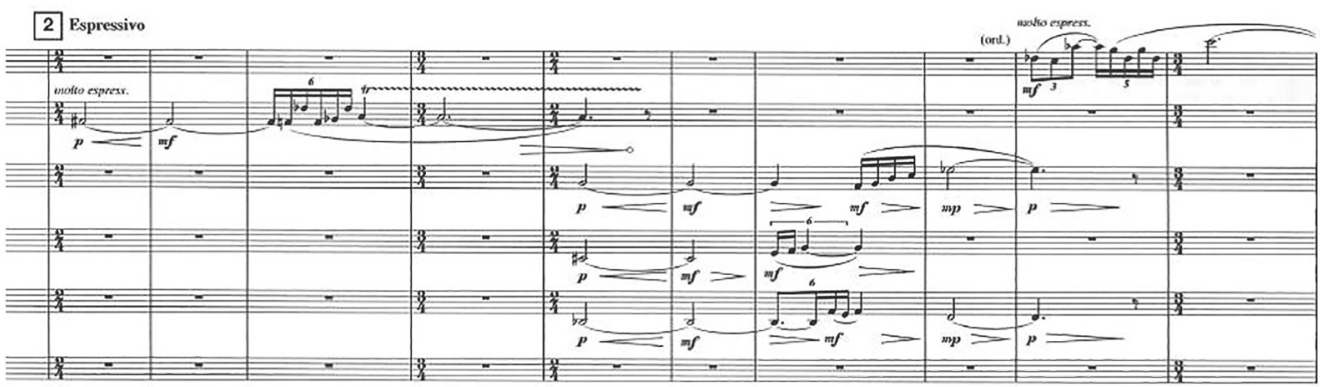

Example 7. Third motive, bars 31-40

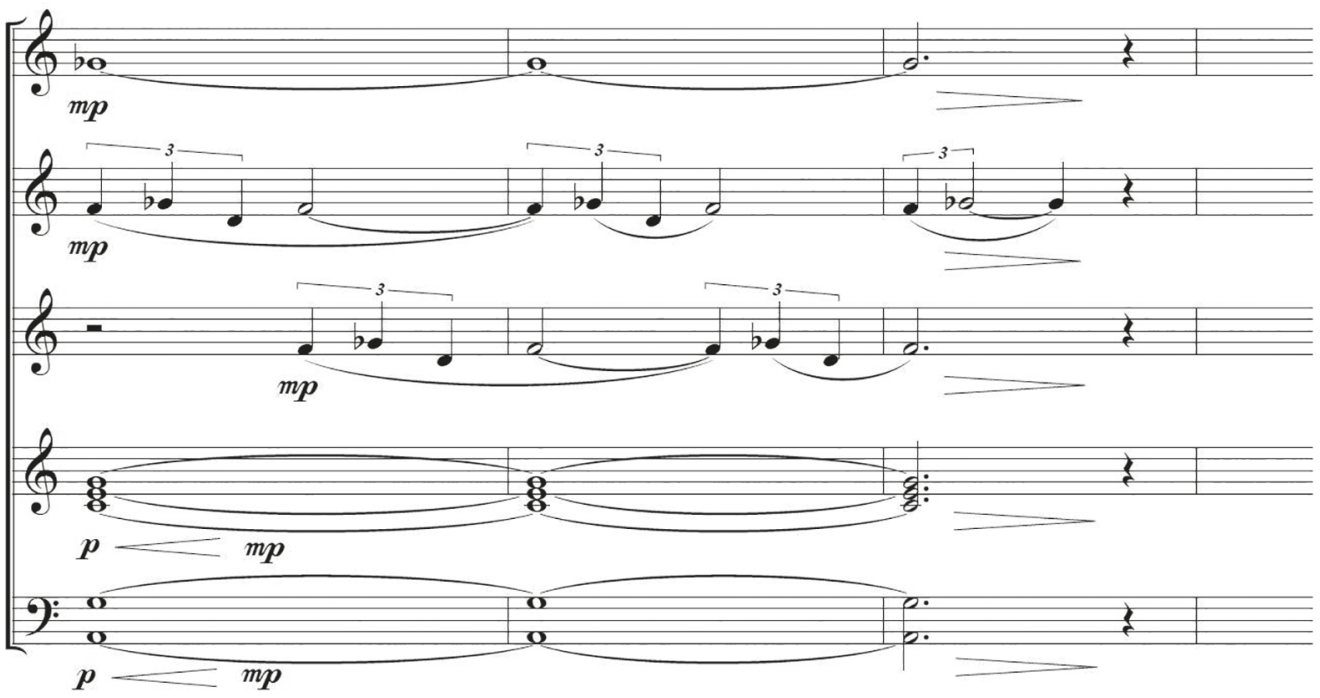

Example 8. Canon in the parts of woodwinds, bars $68-70$

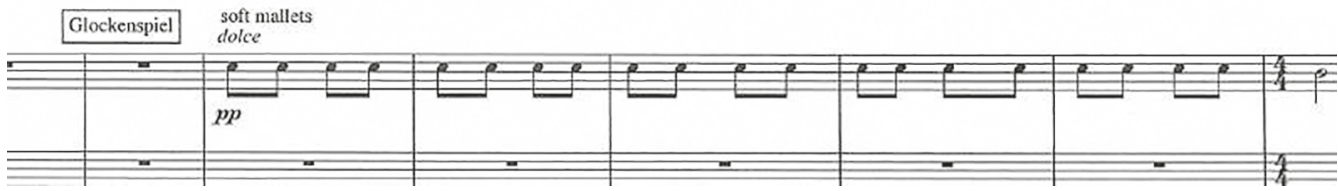

Example 9. Bar 59

mains the main element of the piece. Saariaho also uses recitation in the end of her quartet "Nymphea" where the quartet players recite text by Arseny Tarkovsky.

The third strophe demonstrates visible structural modulation: it is much longer than previous one. What happens here?

Melodical motives begin to develop canonically and this leads to an activation of ostinato structures (ex. 8).

After this, all the music of the $1^{\text {st }}$ section begins to demonstrate various ostinato motives, which increase in quantity. The main ostinato types of the $1^{\text {st }}$ section motives are:

1. Equal-measured ostinato. This means simple iteration of one tone or chords on the extent of several bars (ex. 9). 
As a variant of equal-measured ostinato, an equal-measured motive with contradictory metric design can be considered (contradiction of motive and meter). Though it is a hemiola, we would like to stress its "counter-metric" character according to V. N. Kholopova [19] (ex. 10); or: (ex. 11).
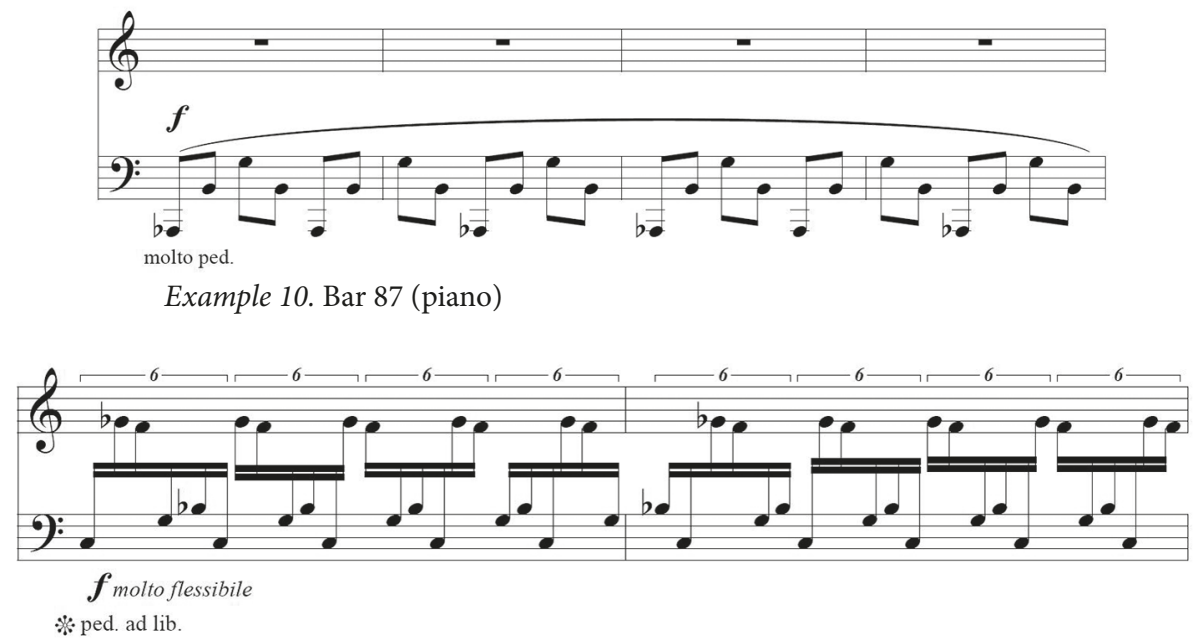

Example 11. Bar 102 (piano)

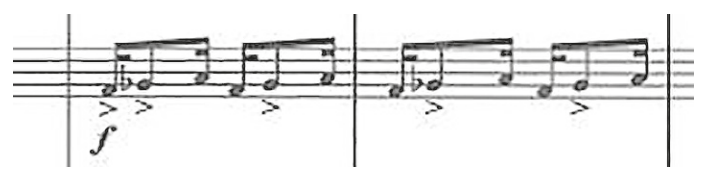

Example 12. Bar 49

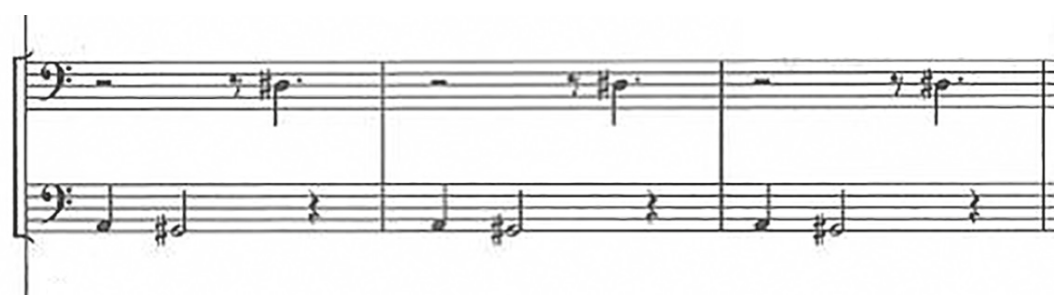

Example 13. Bar 64

2. Non-equal-measured ostinato.

We include here ostinato figures containing different rhythmic structures and we find syncopated rhythmic groups: (ex. 12, 13).

3. Irrational rhythmic structures (ex. 14).

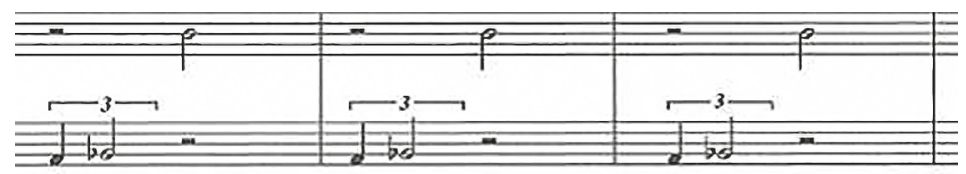

Example 14. Bar 68 


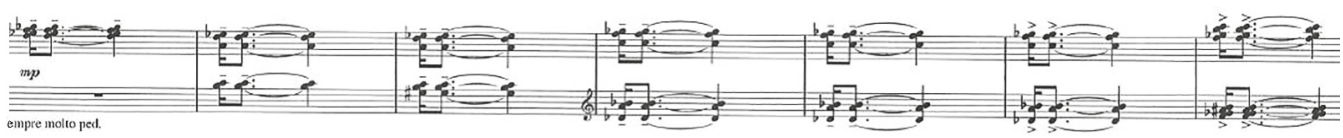

Example 15. Bar 125

Dotted rhythm (ex. 15).

\section{Polyostinato}

Saariaho often superimposes ostinato patterns to construct the polyostinato texture (ex. 16). This multitude of ostinato reminds us of minimalist and post-minimalist compositional techniques which are appreciated by Saariaho herself. Some of the abovementioned includes Morton Feldman's orchestra composition Coptic Light, which was inspired by patterns used in decorative art, particularly in hand-made carpet making, and also by different techniques found in John Adams's and Philip Glass orchestral scores. The renewal and changing of ostinato patterns can be also associated with changing of the background elements in painting.

Ostinato as a principle strengthens itself in the fourth "strophe": we discover a rather autonomous episode which seems to be self-sufficient and is based on a clearly visible basso-ostinato.

Basso ostinato is found in bars 139-211, and the last ostinato iteration serves as an ending of the first part of the piece. Basso ostinato is formed by seven different tones which are found in the piano line in contra octave $(\mathrm{c} 1)$ : $\mathrm{A}-\mathrm{as}-\mathrm{b}-\mathrm{h}-\mathrm{d}-\mathrm{cis}-\mathrm{g}$;

These tones are combined with figuration in the piano part which is constructed as an ostinato of "counter-metric" type (bars 139-143); P. Singleton even treats this succession as a "hidden chaconne" [16, p.67].

This basso ostinato acts as a separate episode, on the one hand, but it also can be considered as an end-to-end structure because of the specific balance of new and quasi-repeated structures. It lacks the power of increasing energy which is characteristic for Shostakovitch ostinatos, for example; it is much more similar to isorhythmic structures where short and laconic repeated rhythms are presented on the long and therefore not very simply recognized melodic pattern in the bass line.

The ending of the first part of the piece can be considered as conditional: the orchestra stops playing and the musicians cite the last lines of the text that conclude with a caesura - fermata, which leads to the second part.

We can draw a conclusion that in this quasi-first part the musical material is unstable and results in specific structural "modulation": the interaction of static prolonged harmonies (horn chords), short melodic structures (quasi-prosodic asymmetric motives) and mystic noises of Sprechchor that step-by-step transform into polyostinato structures that are intervallically bounded with melodic motives. This type of composition has as its basis "process as a form". It raises the question why not "form as a process"? Here we refer to an insight by renowned Russian theorist A. S. Sokolov who wrote:

Treating sound as a living organism in its continuous dynamic development, the composers committed to spectralism conceive a form that emerges from the totality of such sound elements as an entity with inner processual qualities. In doing so, they take up the ideas floating in the 

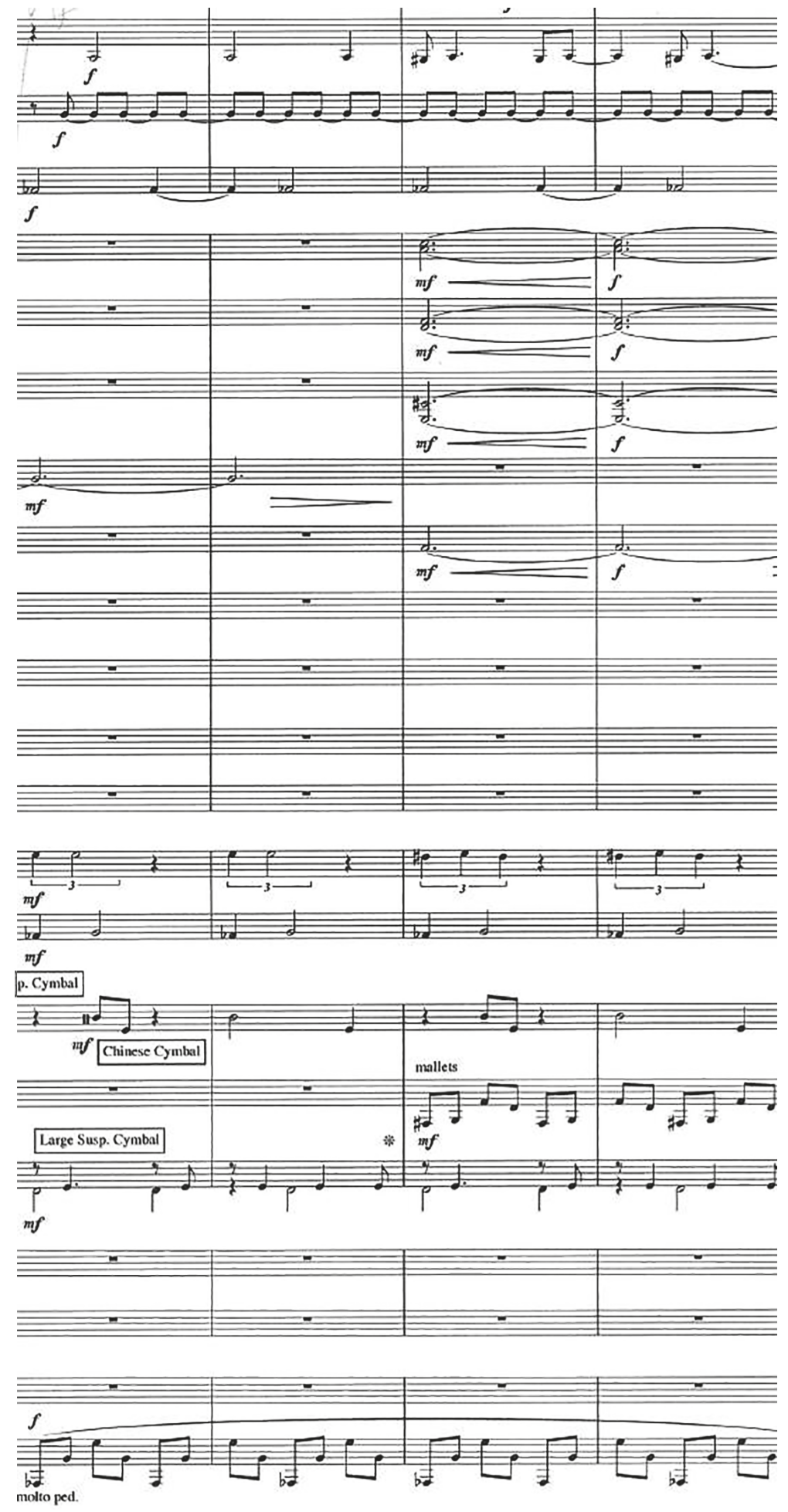

Example 16. Bar 87 
air. Form as a stream in which the phases of durational states show seamless flowing qualities, constitute a novelty characteristic for $20^{\text {th }}$ century music. At the same time, this phenomenon represents well-forgotten 'old ways' appearing as an answer to the increasing concentration of sound events characteristic of last centuries. According to Kholopov, here the process is perceived as a form of music composition rather than form as a process [20, p. 553].

Saariaho has described the same idea in her writings of the 80s: "The plastic arts allowed me to grasp the importance of transitional spaces $\langle\ldots\rangle$ The tensions created by transitional spaces fascinated me most of all as parameters with which it was possible to create musical forms. From these reflections some works resulted in which I tried to fashion a musical dynamic by using abrupt transitions between different materials and thus to compensate for the absence of large-scale tensions within the harmonic material" [15, p. 97]. This specific "passage" forms - as we see it - the inner core of music development of the Laterna Magica's first part.

\section{On the second part}

The second part can be interpreted as a chain of polyostinato structures in different orchestra groups which are divided by short constructions of a type characterized by Saariaho as "music outside visible rhythm or pulse" [11]. Such an alternation of "clocks and clouds", as György Ligeti called it, forms a sort of alternation. We will also consider musical material in order to address the function of compositional laws.

Achieved in the first part, polyostinato combinations become the main material of the second part. Construction of the ostinato structures tends to be more complex and their quantity increases. Ostinato constructions given to the percussion are especially striking: we can see new developments such as distributed ostinato (we feel that it is necessary to suggest this notion for ostinato constructions divided between different timbres) (ex. 17).

In the process of musical development, ostinato constructions begin to lose their differences. They tend to become more and more alike and transform into something like toccata (ex. 18).

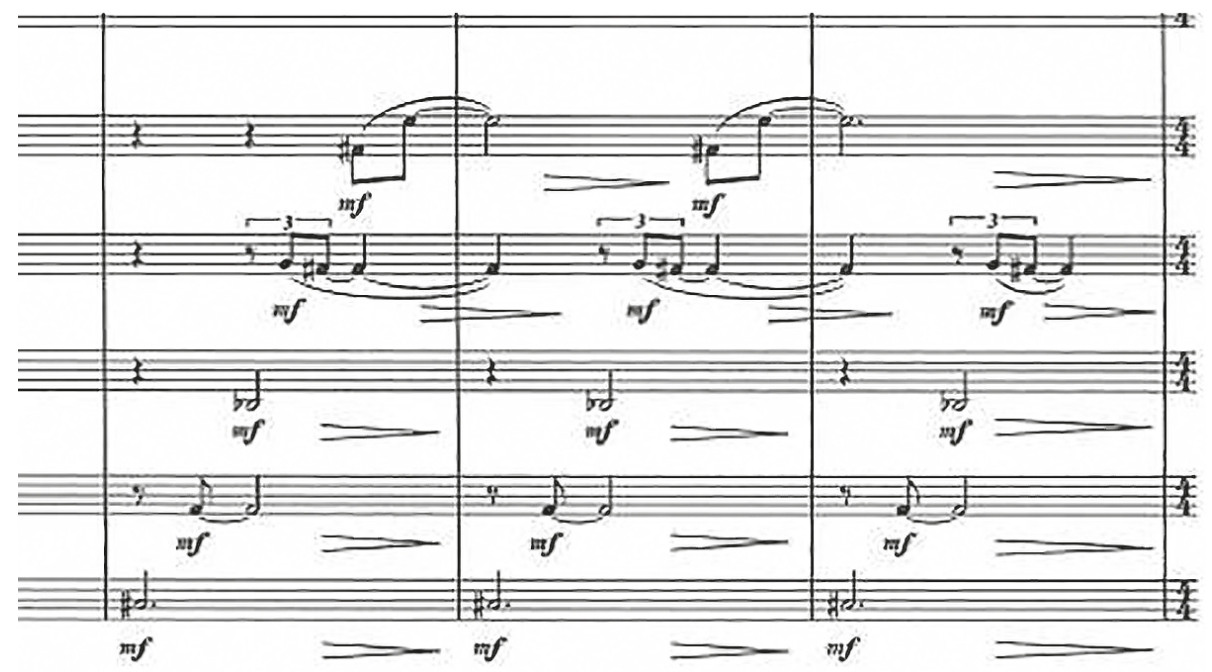

Example 17. Bars 247-249 


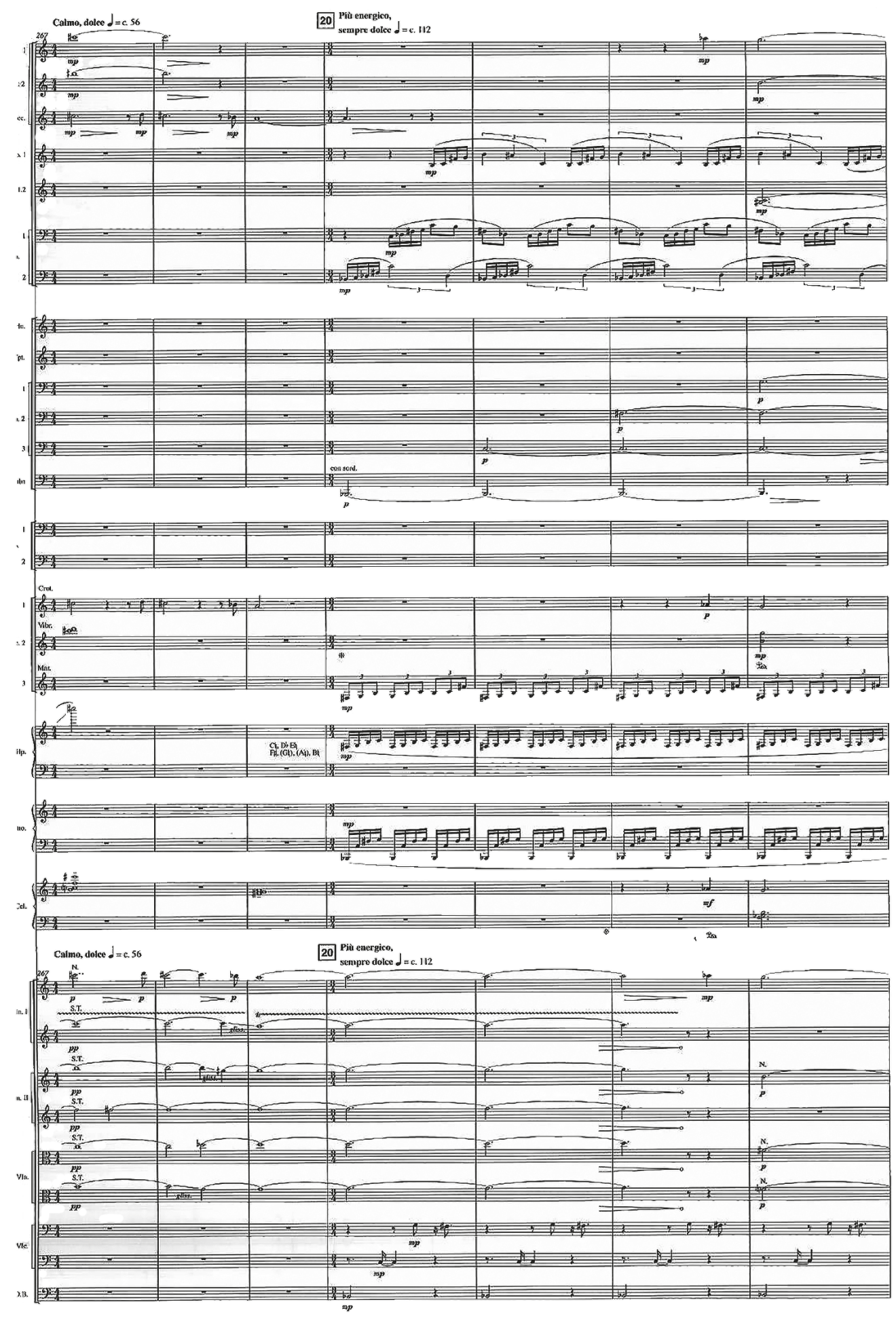

Example 18. Bars 270-274 
32 Reroce $d=c .112$

(1)

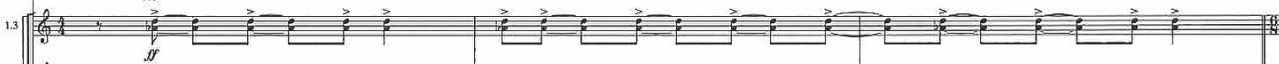

12.5

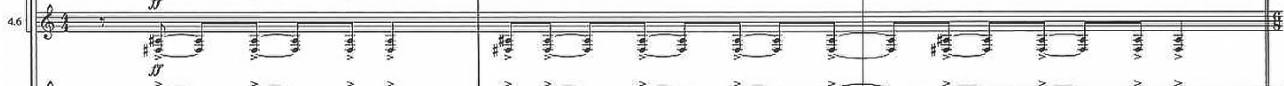

$1 \mid \frac{3}{3}$

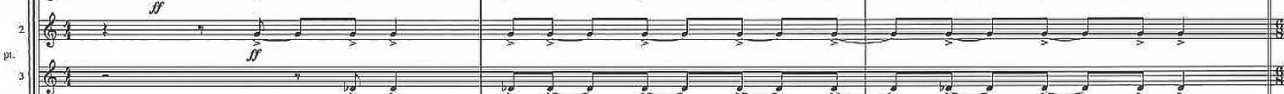

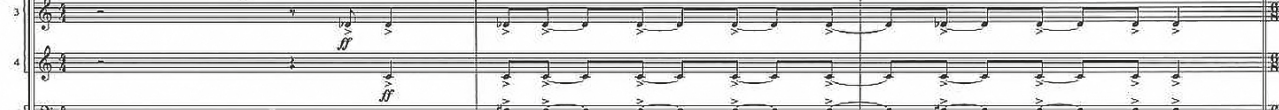

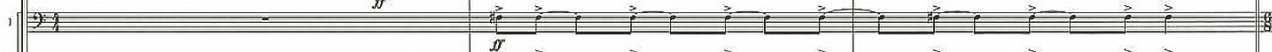

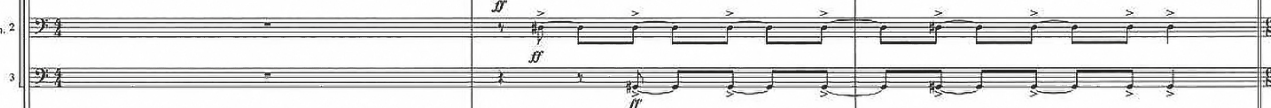

Fata

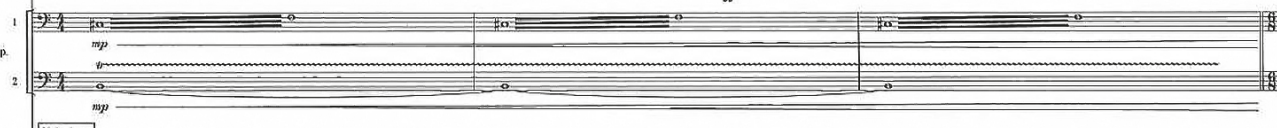

Xyionhane

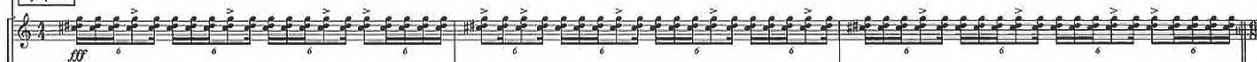

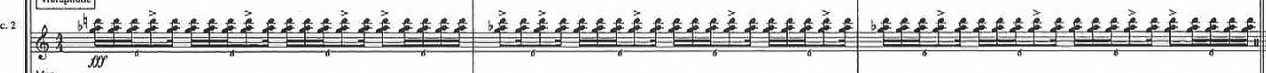

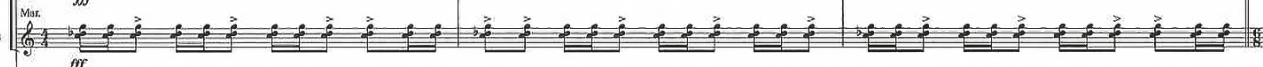
(10.0.

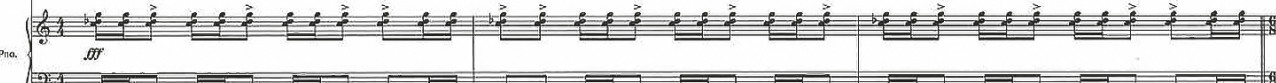

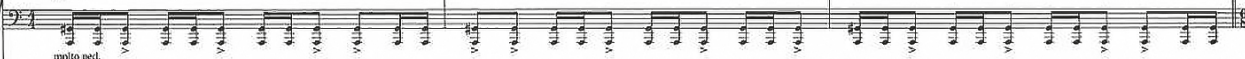

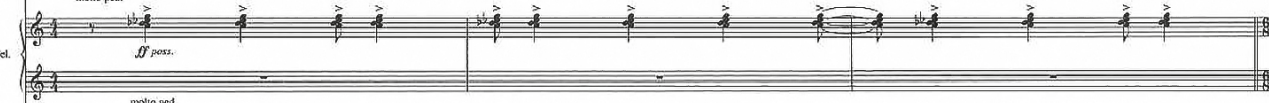

32 Feroce $d=c .112$

Di.

Example 19. Bar 418 
The gradual movement of different rhythmic activities to unified equal-based movement leads to a climax (ex. 19).

This returns twice with a gradually weakening force in bars 471 and 494 . In the first climax, Saariaho used orchestral tutti and after that she excluded timpani and low winds. The horn chord serves as framing for the whole movement in the context of round glissando of harps and violin trill.

\section{Dramaturgic process in music}

We see that the whole line of development in this orchestral piece moves to its climax in bar 418 and then weakens and falls back into a meditative state. Bar 418 is in fact a "golden section" division, which reminds us of classical form laws. The musical movement in the "first part" increases from stasis to dynamic ostinato waves, in the second part - in the direction from more rhythmically complex events to their simplification in climactic points and a further decrease in the energy of development, a swift weakening of the energy and a return to the starting point - the horn chord. In a way, the whole process could be compared to a "magic lantern" cycle: a slow beginning when turning the handle of the machine, then gradual acceleration up to the climax where the separate pictures turn into a continuous moving image, and after the climax we hear a gradual deceleration back to the initial tempo and - as a result - to separate pictures.

\section{Working with tempos}

Tempo shifts are extremely characteristic for this score. 542 bars of the piece are divided by 43 changes of metronome markings. Along with tempo markings Saariaho also places Italian designations with affect characteristics, which can be put in scheme.

Speaking about accordance of the author's tempo idea with its realization ("variation of musical motifs at different tempos"), we can, first of all, see the realization of the idea "doubling the speed". It is presented in two variants: a doubling of metronome markings and a designation of doppio movimento (doppio movement).

The doubling of metronome markings are apparent in correlation crotchet $=48$ and $96(48 \times 2)$ as well as crotchet $=56$ and crotchet $=112(56 \times 2)$. Doppio movimento is used four times in the score in bars 17-19, 85-87, 106-110, 112-121. All of them are incorporated into the $1^{\text {st }}$ part.

Doppio movimento each time is connected with short contrasted constructions where soft and loud, passive and active, dreamy and aggressive are opposed. Although the themes are different, we can interpret this discourse as a similar one to question-answer structure.

The slowest tempo in the composition is crochet $=48$. It dominates in vast episodes in the first part as well as in the second. Mostly this tempo is paralleled with "calmo" designation, which in the middle section is sometimes changed to "intense". Its appearance in the first part, in general, is synchronized with the horn chord. The image of this chord can be associated, despite its dissonant sound, with a romantic mystic sound: we can recall "Oberon horn" from Weber's Oberon or the Schicksal motiv from Gotterdammerung by Wagner. In this slow motion the metronomic marking crochet $=48$ does not reveal itself, it is mostly connected to the duration of the chord and general "mysticism" of the sound: quiet, viscous, and ductile. It can be interpreted as a sign for a conductor: the chords are extremely static and move slowly. Continuing the comparison of the red colour as symbol 
Table. Tempo Changes

\begin{tabular}{|c|c|c|}
\hline Bars & Designation & $\begin{array}{l}\text { Metronome markings } \\
\text { (in crochets) }\end{array}$ \\
\hline $1-5$ & Grave, calmo & 48 \\
\hline $6-13$ & Doloroso & 66 \\
\hline $14-16$ & Calmo & 48 \\
\hline $17-19$ & Doppio movemento & - \\
\hline $20-22$ & Misterioso & 56 \\
\hline $23-30$ & Calmo, espressivo & 48 \\
\hline $31-41$ & Espressivo & - \\
\hline $42-49$ & Misterioso, molto calmo & - \\
\hline $50-52$ & Subito energico & 96 \\
\hline $53-56$ & Piu calmo ma sempre intense & 48 \\
\hline 57 & Energico & 96 \\
\hline $58-59$ & Calmo & 48 \\
\hline $60-64$ & Piu energico ma dolce & 96 \\
\hline $65-79$ & Calmo, molto espressivo & 66 \\
\hline $80-84$ & Misterioso intense & 56 \\
\hline $85-87$ & Doppio movemento & - \\
\hline $88-95$ & Sempre energico, ben sonante & 66 \\
\hline $96-101$ & Maestoso poco grave & - \\
\hline $102-105$ & Intenso ma calmo & 48 \\
\hline $106-110$ & Doppio movemento, energico & - \\
\hline 111 & Grave, intenso & 48 \\
\hline $112-121$ & Doppio movemento & - \\
\hline $122-124$ & Grave intenso & 48 \\
\hline $125-138$ & Dolce, energico & 112 \\
\hline 139 & Subito dolce, misterioso & 56 \\
\hline 152 & Calmo, dolce & - \\
\hline 159 & Dolce ma intenso & - \\
\hline 190 & sempre espressivo & - \\
\hline 222 & molto intenso, meno mosso & - \\
\hline $226-230$ & Espressivo, calmo & 112 \\
\hline $231-232$ & Intenso ma sempre calmo & 56 \\
\hline 233 & poco piu energico & 112 \\
\hline 239 & poco agitato & \\
\hline 254 & Sempre intense, energico & 56 \\
\hline 257 & - & 112 \\
\hline
\end{tabular}


End of the Table

\begin{tabular}{|c|c|c|}
\hline Bars & Designation & $\begin{array}{l}\text { Metronome markings } \\
\quad \text { (in crochets) }\end{array}$ \\
\hline 267 & Calmo, dolce & 56 \\
\hline $270-285$ & Piu energico & 112 \\
\hline $286-291$ & dolce & 56 \\
\hline 292 & agitato & 84 \\
\hline 314 & - & 48 \\
\hline 316 & molto energico & 84 \\
\hline 362 & $\begin{array}{l}\text { piu energico ma sempre } \\
\text { espressivo }\end{array}$ & 56 \\
\hline 381 & fermamente & \\
\hline 418 & feroce & 112 \\
\hline 421 & furioso & 112 \\
\hline \multicolumn{3}{|l|}{424 g. p. } \\
\hline \multicolumn{3}{|l|}{432 g. p. } \\
\hline 439 & Subito meno mosso. Doloroso & 66 \\
\hline 446 & piu mosso & 112 \\
\hline 452 & Subito calmo & 48 \\
\hline 458 & Molto energico & 112 \\
\hline 471 & Feroce & 112 \\
\hline 483 & Doloroso & - \\
\hline 494 & Furioso & - \\
\hline 499 & Meno mosso. Delicato & 56 \\
\hline 502 & piu mosso espressivo & 66 \\
\hline 524 & Intenso, grave & 48 \\
\hline $525-531$ & Piu mosso & 66 \\
\hline $532-536$ & Misterioso & 56 \\
\hline $537-542$ & Poco grave & 48 \\
\hline
\end{tabular}

of emotion in the film Cry and Whisper by Bergman, we can compare the colour of this chord to violet, cold and mystic, dark and dim. The appearance of the chords makes the movement obstructed and the colouring dark.

The doubling of metronome $=48$ is metronome $=96$. This tempo is paired to designation "energico", and we encounter this tempo in places where the texture changes to ostinato structures. This tempo has often been used in the first part, but it is absent in the second part. No special effect connected to the doubling of tempo has been discovered.

Two tempos are interim between slow and fast - 56 and 66. Metronome marking 56 is connected to Sprechchor as well as designation Misterioso. Metronome 66 can be interpreted as an intermediate step between 48 and 96, this tempo is most common for the sections with melodic motives. 
The second part is fully designed in tempos metronome $=56$ and 112 . In the aural perception, this difference is not very clear since double speed is not distinguished when motive structures are contrasting and there is no common ground to compare durations. However, such tempos as metronome $=112$ and 56 belong to different characters and it is obvious that this doubling of the speed is partly external. Tempo metronome $=112$ is used in the most rapid, "frantic" sections of the second part and particularly climactic sections.

\section{Affects}

In addition to tempos, Saariaho also designates affects. Calmo, doloroso, misterioso, espressivo, energico, intenso, dolce, agitato, maestoso, feroce, furioso - this is a well-known and understandable set of affects which tells us about a wide range of feelings associated with romantic imagery close to the Lisztian. The fact of designating such affects is remarkable. Saariaho makes these designations not for the first time - for example, similar romantic characteristics are also encountered in Nymphea Reflection (the orchestral version of string quartet Nymphea). The composer explained her approach in the following words: "The music I compose is peered towards the human spirit, about writing profound music, very profound" [21, p. 8-9]. These words can be interpreted as a position which seems very close to the Romantic one: Saariaho seeks beauty and concentration; maybe that is why one of her preferred designation in the scores is "misterioso": she wants sentiments and sensations.

\section{Harmony}

On the role of harmony Saariaho wrote: “...The only common factor between the different materials is harmony which, paradoxically, becomes the most stable element of all" [15, p. 97]. What is necessary for harmony to become a stabilizing factor?

As the composer herself claims "it is by modifying the speed of modifying harmony's development, that harmonic tensions are created, by making harmony into a strict controlled parameter. To achieve this, I worked on degree of differentiation of successive chords and on the linear duration of each chord" [15, p. 97]. Expression used by Saariaho - "differentiation of successive chords" - is noteworthy. What is the point she tries to emphasize here?

Saariaho considers as a crucial factor for general contour of the composition the harmonic motion, which represents the smoothest motion between two polarities. She implemented such a technique in the piece Vers le Blanc for electronics: "The fundamental idea of this piece is the very slow transition from one chord to another through glissandi, which are so slow that changes in pitch become imperceptible to the ear" [15, p. 104]. Although this composition was, as Saariaho confirmed, "an experimental one", the idea of extremely continual transition from one point to another was expressed clearly (ex. 20).

In Laterna Magica, harmonic progression is very explicit: the chord played by six horns begins to perform this "general bass" throughout. P. Singleton traces its origin from a section of spectra from "g" of counter - octave (ex. 21).

Here, all the chords used in Laterna Magica are presented in direct succession (ex. 22).

In this table, the general quantity of chords is collected, but it seems necessary to consider not only a collection but specifically a succession of chords as long as it is crucial for a conception of the composition. The main idea for Saariaho was the following: a process of "interpolation" is used to acquire a harmonic line. Its essence can be illustrated by the 


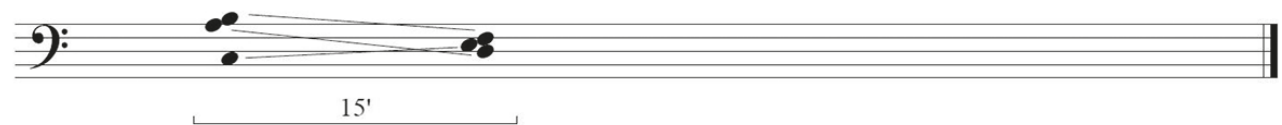

Example 20. Scheme of Vers le Blanc

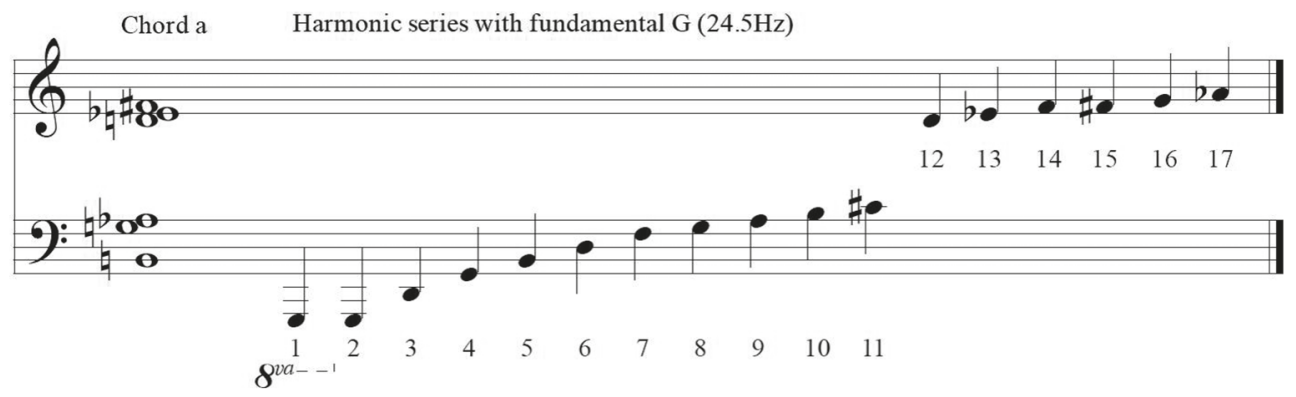

Example 21. Spectra of the initial chord [2, p. 63]
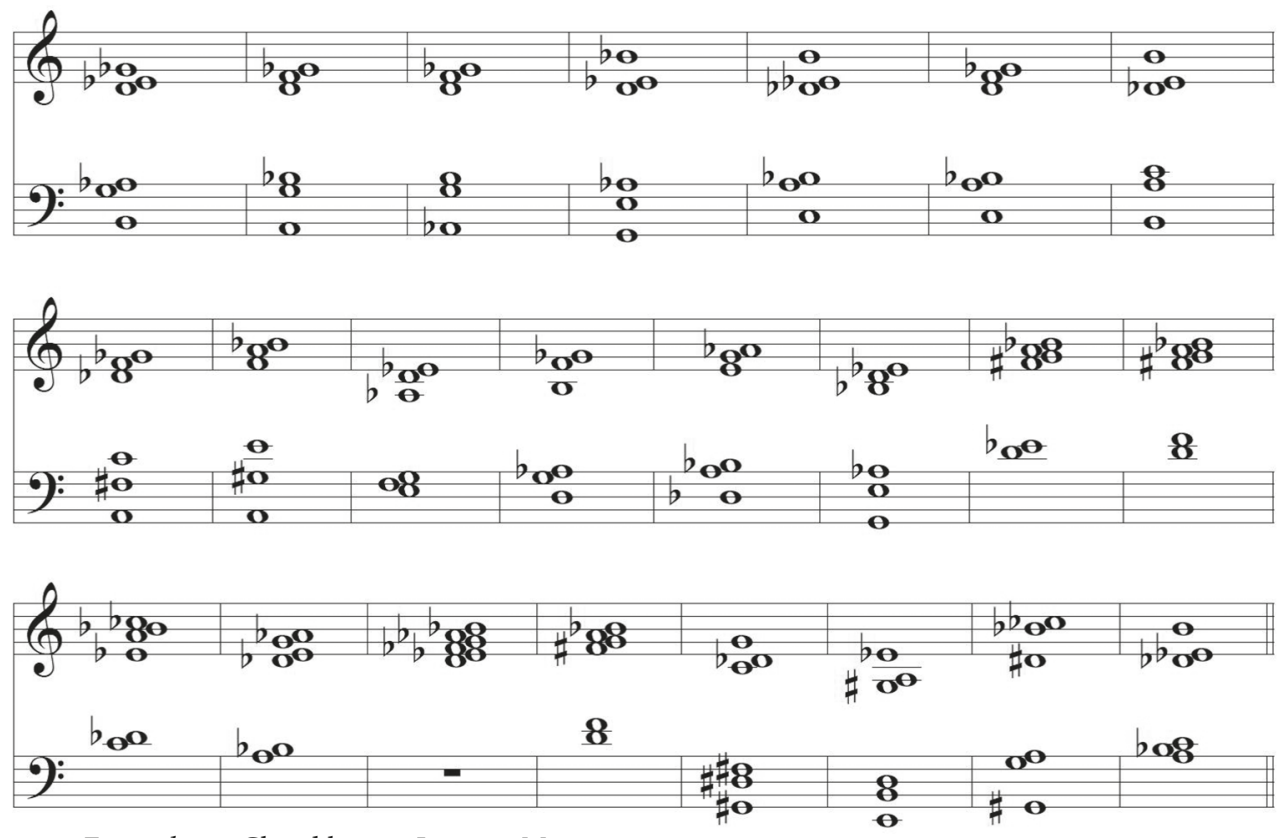

Example 22. Chord line in Laterna Magica

following: between the first and the last chord, a chain of intermediate harmonies is introduced where the changes lead from the first chord to the last.

Due to this, we made a reduction of the chord line: basic harmonic succession includes only self-sufficient horn chords which are not included into tutti episodes and thus represent harmonic support. This succession makes it possible to see links between different voices of the chord (ex. 23).

It is interesting to compare the result of the previous analysis with the example from Saariaho's orchestral piece Verblendungen where she explains the phenomenon of interpolation (ex. 24). 
TT.

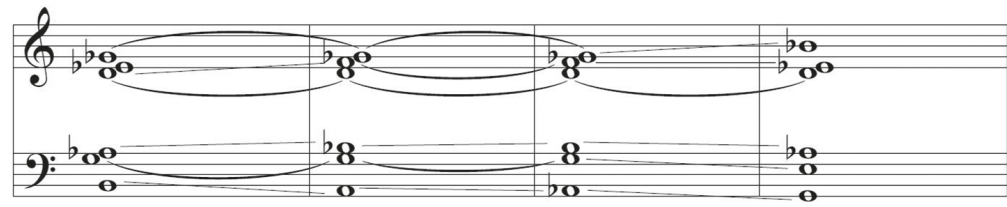

T9

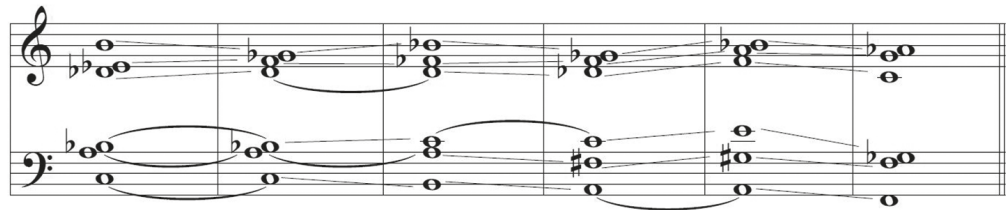

Example 23. Reduction of chord line

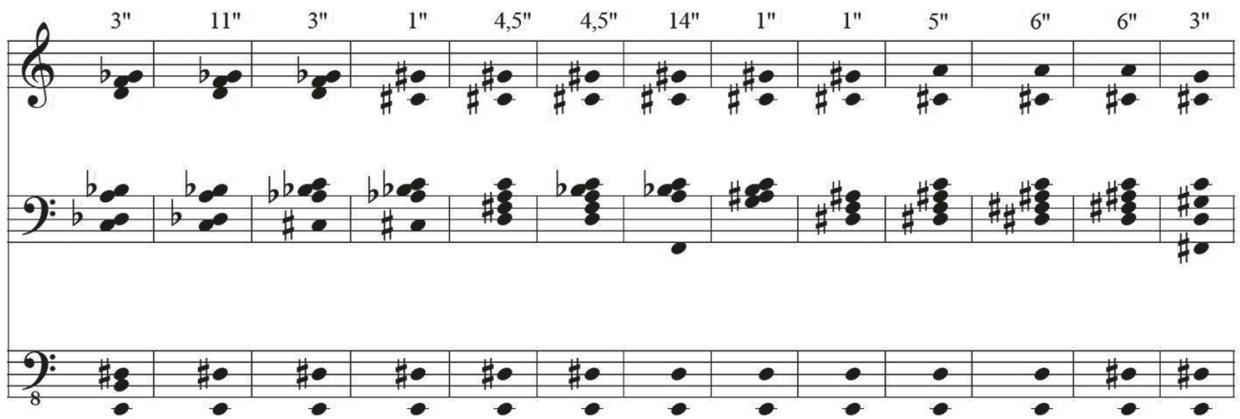

$\bigodot_{7 \bullet}^{\circ}$
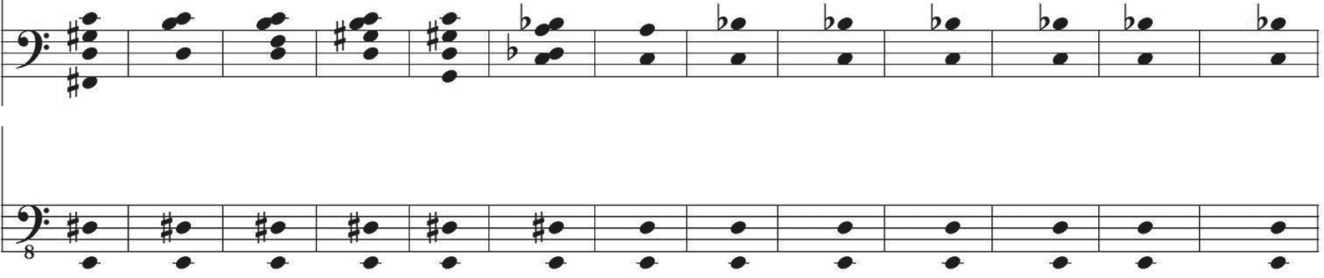

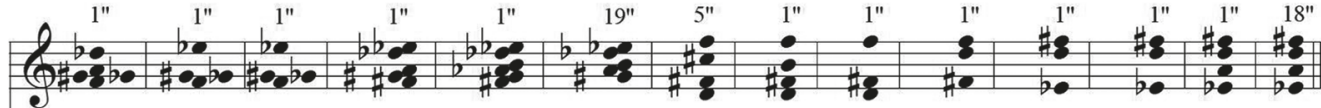
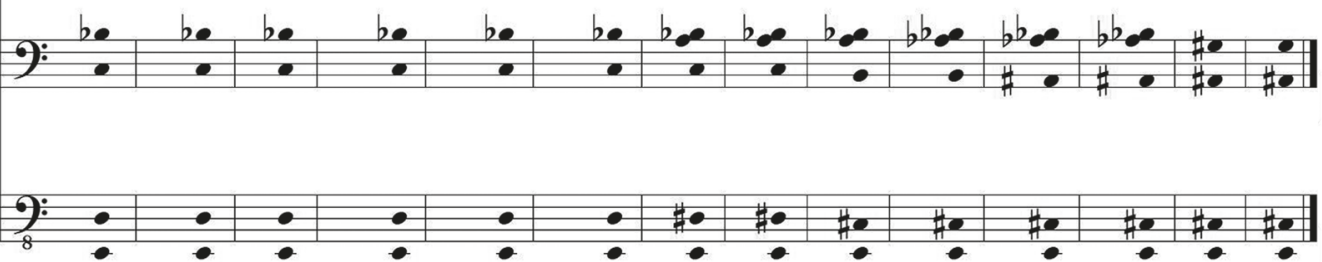

Example 24. Saariaho K. Verblendungen, scheme of interpolation [15, p. 109] 
The voice-leading in these multi-voiced chords seems to demonstrate almost traditional qualities combined with the principles of spectral harmony. The succession of chords achieved with the interpolation method is intertwined throughout the whole piece and realizes the inner control of pitch content.

Chordal pitch content also can be effectively analysed with set theory procedures. The result of such an analysis can explain the choice of pitch elements through similarity relations which obviously helps to form the feeling of harmonic homogeneity and unity of color (see, for example, [22]).

All this leads us to the analysis of the main compositional means in Saariaho's piece: "polyphony of processes".

\section{"Polyphony of processes"}

What are the processes which form this polyphony? We can identify some trends which form this kind of polyphony: text-and-music process, tempo process, harmony process.

\section{Text-and-music process}

The combination of text and music is characteristic for the first part of the piece and the process of its realization has a gradually increasing dynamic. We would designate it as "crescendo" figure expiring in bar 224. The text vanishes after this point.

\section{Tempo changes}

Tempo changes make it possible to see different approaches, which could be interpreted as six sections of tempo ideas.

The process of tempo changes has the following dynamic:

First section (bars 1-22) 48-66-48-56-

Second section (bars 23-64) 48-96-48-96-48-96- [relation 1:2]

Third section (almost the same as the first) (bars 65-124) 66-56-66-48-

Fourth section (bars 125-291) 112-56-112-56-112-56-112-56-112-56- [relation 1:2]

Fifth section (bars 292-498) 84-48-84-56-112-112-66-112-48-112-112-

Sixth section (bars 499-542) 56-66-48-66-56-48

As we can see, the composer uses a sort of tempo play: while such line of tempi as in the first, third, and sixth sections demonstrate something close to "rubato" phenomenon where tempi change almost gradually, tempi in sections two and four demonstrate abrupt changes in relation 1:2. The fifth section has a specific row of tempos, they change intensively and this "tempo swing" is superimposed on the approaching climax.

\section{The dramaturgy processes}

Dramaturgy is not a common concept considered as characteristic for spectral or postspectral music; this concept is more common for classical music [16]. The dramaturgic process in Saariaho's piece is characterized through a motion from the beginning to the climax (bars 418-420). This moment is stressed by texture and rhythmic unity which 
is of the utmost quality in the whole piece. Should we consider this open movement to the climax as a component of the composer's theatrical thinking? Possibly yes - Saariaho became an opera composer since her debut with the opera Amour de Loin (2000), which received great acclaim, and up to 2008 (the year of completing Laterna Magica) she was the author of two more operas - Adriana Mater (2005) and Emilie (2008).

\section{Harmony process}

The harmony process can be described optimally by Saariaho's words which she wrote on Verblendungen in her cited article on timber and harmony:

From the harmonic point of view, however, the result is surprisingly homogenous. The different structures are not perceived separately, at least not in an awkward way. Three factors helped to bring this about. The first is the fold-over of the chords: the range of pitches in the work is really a very precisely determined parameter, as previously shown. At the beginning it occupies a restricted area, and proceeds to grow throughout the duration of the piece. Initially the notes which threaten to exceed the given limits are retrieved by fold-overs.

The second factor is the speed of the harmonic progression, which is very slow at the beginning since the transition from one chord to another occurs via a note-by-note progression, whilst further on changes without such an intermediary stage. This rate of progression was also minutely calculated, and before beginning the work of composition I devised a map for the overall harmonic structure of the work - comprising the exact duration of each sequence $<\ldots>$.

The third factor which effectively limited the heterogeneous qualities of the harmony in a decisive way was, finally, my ear. It is that which ultimately determines the existence of each chord, thus making the totality more homogeneous. With the ear I always found a means of remodelling an uninteresting chord, often without even breaking the rules that I had fixed to myself $[15$, p. 122].

All this can be summarized by Saariaho's words on interpolation: "The change of pitch is so slow that you can't hear it, but $\langle\ldots\rangle$ you do perceive that the harmonic structure is changing gradually" [15, p. 104]. Feeling harmony as one of the key factors in her output, Saariaho demonstrates the turn to a classical understanding of the term: she carefully seeks a backbone of the composition and finds it in harmonic succession, which she derives from the spectral content of the chord but also transforms with her own hearing and adding the law of interpolation that seems strangely close to the law of voice-leading in classical harmony. The specific feature of this so-called "voice-leading" is its speed - it is so low that one cannot perceive the harmonic process as something teleological and the colouring of the harmony begins to play the most important role.

\section{Conclusion}

The more we analyse the piece, the more Saariaho's text in her author's programme is a striking feature. The properties of music itself described by the author are not easily found in the process of analysis and seem to be even some sort of problematic.

It seems necessary to recall some basic ideas of the Laterna Magica provided in Saariaho's comments:

1. "The variation of musical motifs at different tempos emerged as one of the basic ideas behind the orchestral piece on which I was beginning to work". 
2. "Rhythms with different characters became a major part of the piece's identity: a fiery dance-rhythm inspired by flamenco, a shifting, asymmetrical rhythm provided by speech and an accelerating ostinato that ultimately loses its rhythmic character and becomes a texture";

3. "Music without a clear rhythm or pulse. This material is dominated by strongly-sensed colourful planes and airy textures, such as the unified colour of six horns, which divides the orchestral phrases" [11].

What can be qualified as "the variation of musical motifs at different tempos"? Where can a fiery dance-rhythm inspired by flamenco be found? In which way does the chord played by six horns divide orchestral music into phrases?

We believe that the variation of musical motives in different tempos in comparison to the real tempo is not too obvious. The real effect is much closer to a contradiction of motive and meter which is quite notable and vivid. The effect of such a contradiction is great: accents placed on different planes and levels of musical material literally "electrify" the musical narrative.

Clearer is the status quo of "asymmetrical motives" and textures, merging into the united motion. We can point at motives-questions, motives-invocations with their wide intervals, filled with the energy of overcoming this interval distance. Wide interval melodic leaps were often practiced in European art music and the fact that Saariaho manages not to be similar to other composers (or, differently, tends to be similar to many others in a way which allows to consider her motives as topoi) - all this points to her exceptional compositional craft.

The question about flamenco remains open. "Fiery flamenco motives", if one treats this expression literally, should represent some kind of widely known compáses. But there are none of them! The most "fiery" musical material is presented by rhythmic structures in climax sections but are they really flamenco structures? We would be better to remember tarantella motives with its really fiery motion in $6 / 8$ meter. Should we consider this as an artistic misuse? Or the magic of flamenco image in the program should just inspire the listeners?

The music with a shifting and asymmetrical rhythm really appears, but it is not so distant from regular rhythm as the composer notes. It has a sort of inner rhetoric; it contains the energy of exclamations. And stylistically it fits into this magic harmony of horn chords, mystic and charming as the Oberon motive by Weber. And the chords they do not divide the narrative, they have their own thread which is rather independent from other elements. Superposed processes of different parameters' development create the effect of a flickering form, a highly developed "polyphony of the processes".

Therefore, what is the inner core of the Laterna Magica music? Should we consider it a virtual soundtrack to Ingmar Bergman's life story? Or is it a separate work of art with its own laws that are only inspired by Bergman's book?

Saariaho's piece fits into the line which was began with her Amers (1992) for cello and chamber ensemble: in Amers she used some features of instrumental concerto concept without being true to its external similarity. In the same manner Laterna Magica reminds us of a romantic tone-poem without symphonic development. Instead, she develops the narrative of her composition with compositional means which are new and individual. The idea of "polyphony of processes" makes it possible to produce the texture of outstanding smoothness where you can hear different shades of instrumental colours, a 
change of textures, and above all the true Saariaho's affect which can be sensed throughout the composition - a sense of mystical beauty and harmony which she artfully puts in a different light.

Bergman put particular emphasis on "light", and Saariaho, as we see, caught onto the idea, carefully changing the harmonies made of sound spectra - shall we distinguish there a technique which reminds us of Skryabin and his "mystic chord"?

Playing with different ostinatos could be interpreted as a development of rotation idea, which can be associated with the constructional principle of Laterna Magica itself the spinning picture provides the continuous image, continuous time, and continuous magic of cinema. And the game of tempos performs the same role - they demonstrate the unlimited possibilities of cinematograph, its ability to accelerate and slow down the time in its entirety. However, all these ideas are subject to feeling - to affects. Dolce, furioso, doloroso, misterioso - these words are designations of feelings, which are very sublime, but they contain true charm and even magic which are so intrinsic to Saariaho's music and her style.

\section{References}

1. Pousset, Damien. “The Works of Kaija Saariaho, Philippe Hurel and Marc-André Dalbavie - Stile Concertato, Stile Concitato, Stile Rappresentativo”. Transl. by Joshua Fineberg and Ronan Hyacinthe. Contemporary Music Review 19, pt. 3 (2000): 67-110.

2. Deliège, Célestin. "Atonal Harmony: From Set to Scale". In Contemporary Music. Theoretical and Philosophical Perspectives, ed. by Irène Deliège and Max Paddison, 51-77. Farnham: Ashgate, 2010.

3. Manoury, Philippe. La musique du temps reel. Entretiens avec Omer Corlaix et Jean-Guillaume Lebrun. Paris: Éditions MF, 2012.

4. Moisala, Pirkko. Kaija Saariaho. Urbana; Chicago: University of Illinois Press, 2009. (Women Composers).

5. Howell, Tim, Jon Hargreaves, and Michael Rofe, eds. Kaija Saariaho: Visions, Narratives, Dialogs. Farnham: Ashgate, 2011.

6. Skhaplok, Galina. Music of Kaija Saariaho. Moscow: Kompozitor Publ., 2017. (In Russian)

7. Tsaregradskaya, Tatiana. Musical Gesture in Space of Modern Composition. Moscow: Kompozitor Publ., 2018. (In Russian)

8. Bergman, Ingmar. Laterna Magica. Rus. ed. Transl. by A. Afinogenov. Moscow: N Publ.; AST Publ., 2019. (Ekskliuzivnaia klassika). (Knigi, izmenivshie mir. Pisateli, ob”edinivshie pokoleniia). (In Russian)

9. Nieminen, Risto. "Kaija Saariaho: 'At the Moment the Computer and I Belong Together". Accessed August 24, 2021. https://fmq.fi/articles/kaija-saariaho-8220-at-the-moment-the-computer-and-i-belong-together.

10. Saariaho, Kaija. "My Library, from Words to Music”. Transl. by Jeffrey Zuckerman. Music and Literature, no. 5 (2014): 12-5.

11. "Laterna Magica”. Kaija Saariaho. Accessed June 16, 2021. https://saariaho.org/works/laterna-magica/.

12. Kosman, Joshua. “Saariaho's 'Laterna Magica' is a Winning Jumble of Ideas”. SFGATE. Accessed June 16, 2021. https://www.sfgate.com/music/article/Saariaho-s-Laterna-Magica-is-a-winning-6572310.php.

13. Cadagin, Joe. "Berkeley Symphony Explores Light Music". San Francisco Classical Voice. Accessed June 16, 2021. https://www.sfcv.org/articles/review/berkeley-symphony-explores-light-mu$\mathrm{sic}+\& \mathrm{~cd}=1 \& \mathrm{hl}=\mathrm{ru} \& \mathrm{ct}=\mathrm{clnk} \& \mathrm{gl}=\mathrm{ru}$.

14. Anderson, Colin. "Prom 5: Also sprach Zarathustra... Laterna magica". Accessed June 16, 2021. https:// www.classicalsource.com/prom/prom-5-also-sprach-zarathustra-laterna-magica/.

15. Saariaho, Kaija. "Timbre and Harmony: Interpolations of Timbral Structures". Contemporary Music Review 2, iss. 1 (1987): 93-133. https://doi.org/10.1080/07494468708567055.

16. Singleton, Philip. "Spectralism Today: A Survey of the Consequences for Contemporary Composition of the French Spectral School of the 1970s and 1980s". PhD Thesis, University of Surrey, 2015. 
17. Harmeyer, Jackson. "Liminal Aesthetics: Perspectives on Harmony and Timbre in the Music of Olivier Messiaen, Tristan Murail, and Kaija Saariaho”. Master's Thesis, University of Louisville, 2019. https:// doi.org/10.18297/etd/3177.

18. Anderson, Julian. "A Provisional History of Spectral Music". Contemporary Music Review 19, pt. 2 (2000): 7-22. https://doi.org/10.1080/07494460000640231.

19. Kholopova, Valentina. Music Theory: Melody, Rhythm, Texture, Thematism. $2^{\text {nd }}$ ed. St. Petersburg: Lan' Publ.; Planeta muzyki Publ., 2010. (Uchebniki dlia vuzov. Spetsial'naia literatura). (In Russian)

20. Sokolov, Aleksandr. "Spectral Method". In Teoriia sovremennoi kompozitsii, executive ed. Valeriia Tsenova, 548-62. Moscow: Muzyka Publ., 2005. (Academia XXI: uchebniki i uchebnye posobiia po kul'ture i iskusstvu). (In Russian)

21. Mao-Takacs, Clément. "Laile de l’ombre: conversation avec Kaija Saariaho". Tempus Perfectum, no. 11 (2013): 7-14.

22. Meine, Rodrigo. "The Unified Colour and the Division of Orchestral Phrases in Kaija Saariaho's 'Laterna Magica': The Modelling Process as a Guideline for Compositional Decisions”. ART Music Review, no. 32 (2017): s. p.

Received: January 31, 2021

Accepted: August 26, 2021

Author's information:

Tatiana V.Tsaregradskaya - Dr. Habil. in Arts, Professor; tania-59@mail.ru 